\title{
NON-FINANCIAL COMPENSATIONS: A PROPOSAL TO REFURBISH THE OLD RESIDENTIAL BUILDINGS IN BENIDORM (SPAIN)
}

\author{
ARMANDO ORTUÑNO PADILLA \\ Building and Urbanism Department, University of Alicante (Spain).
}

\begin{abstract}
The aim of this paper is to propose an urban intervention in the downtown of a very important tourist city, Benidorm (Spain), taking into account the scarce public funds and the financial crisis as a whole. The core of Benidorm, the most important area for tourism activity, is showing an old-fashion image, with hardly renovation during the last decades. Hence, it is necessary to refurbish the centre of the city dealing with the scarce funds. For that reason, a market-oriented instrument, specifically 'non-financial compensation' instruments, will be suggested to regenerate some specific areas through studying other urban renovations along the world. Firstly, the paper will describe the main characteristics of Benidorm in terms of urban evolution, tourism activity and recent problems related to old buildings located in the core of the city. Next, some international cases where non-financial compensations have been applied will be exposed as a reference to implement in Benidorm. Finally, a proposal to refurbish the old buildings in the centre of Benidorm will be drafted considering those international experiences.
\end{abstract}

Keywords: Benidorm, non-financial compensations, urban regeneration.

\section{INTRODUCTION}

The city of Benidorm is located in Alicante Province, in the Southeast of Spain, with a population of 69,010 people in 2014 [1]. The most important activity is without doubt, tourism. In fact, the average of population - inhabitants plus tourists - all over the year surpasses two hundred thousand [2], and according to the last reliable poll at Alicante Airport, 21.3\% of the passengers travel to Benidorm, which is the most important destiny at this airport [3]. That magnitude shows the big intensity of the tourist activity -tourist rotations - in Benidorm.

The 'New city' of Benidorm was born at the end of the fifties in the 20th century thanks to a land spatial plan, typically called 'Ensanche' in Spanish cities, which is a new land developed area linked to the historical town [4]. But, in this case, the land spatial plan was genuine because it was conceived for tourism activity. In Fig. 1 can be distinguished the small secular city in the centre and next to the sea, with a chaotic urban weave, and on the right side the new area.

The urban weave of the 'Ensanche' has remained with hardly transformations along its half century life. It is composed by two main perpendicular axes - Europe and Mediterranean Avenues - from which the rest of the Ensanche was developed following a grid shape. The buildings inside the plots are exempts and have evolved from its conception of a city garden with detached houses and low density, to 'tranvías -tram- buildings' (long and horizontal buildings) and, later, to even more higher skyscrapers which dominate the current Benidorm skyline and have become in the icon of the city (Fig. 2). In the floor of the plots, there are all kind of activities such as commercial, amenities or services. 


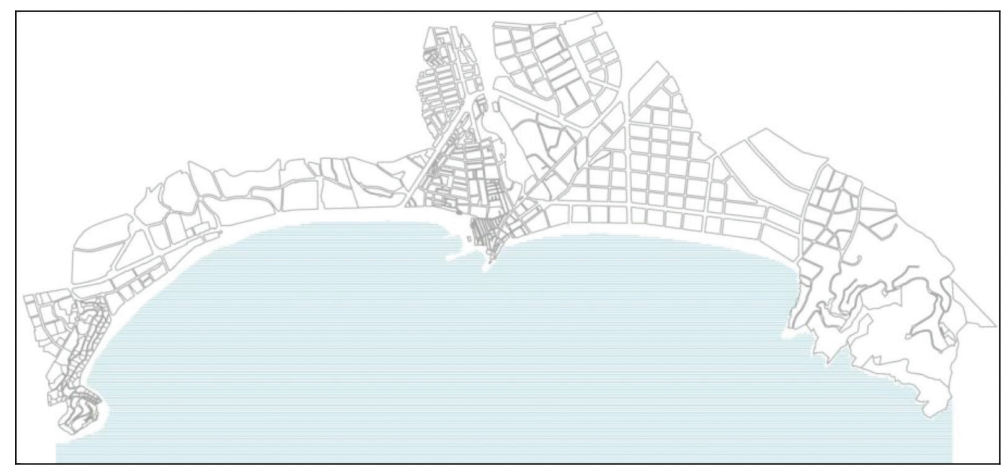

Figure 1: 'Ensanche' of Benidorm in 1953 over the current urban weave.

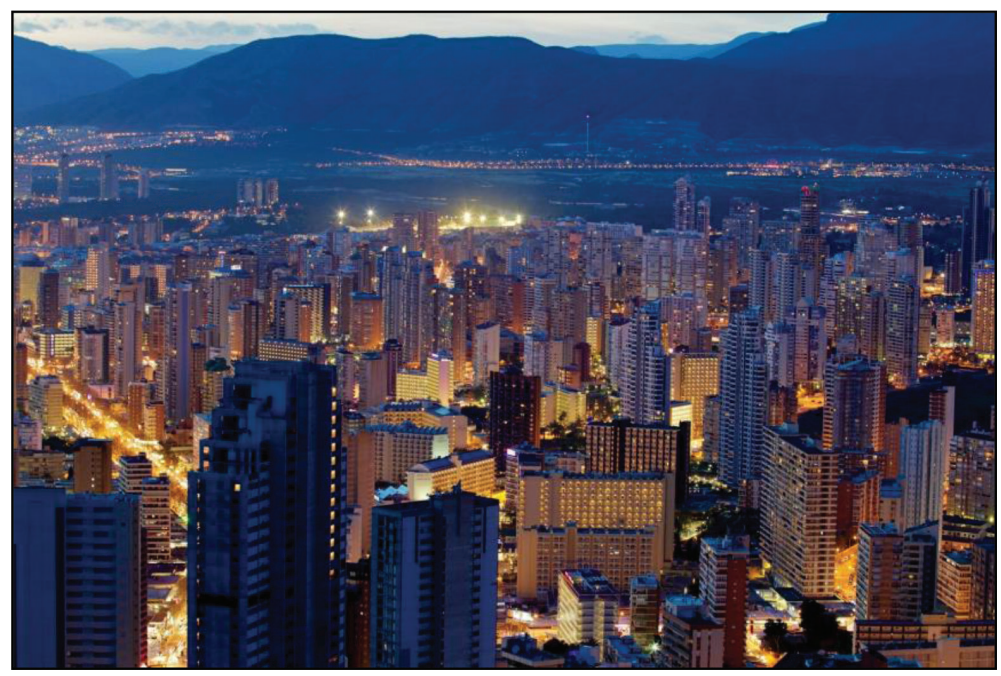

Figure 2: Current Benidorm skyline dominated by skyscrapers.

In that way, the first change from a city garden to the idea of compact city took place at the beginning of the plan, in the early sixties thanks to several modifications on the Land Spatial plans, which allowed to build 'tram buildings' inside the plots instead of detached houses.

The changes took place because of the local landowner, who pressured the local politicians to increase the volume allowed in the plot so that enhance the land price. The issue was what kind of city they wanted to develop: a garden city for rich people or a city with building blocks for mass tourism. Finally, the local government modified the original plan, which was the origin of the current Benidorm, but taking into account the maximum volume in order to maintain the quality of the public space (an over density can generate too much traffic, noise, pollution, etc.).

The mentioned evolution from detached houses to 'tranvía buildings' and the current skyscrapers deserves to be explained. Thus, the total volume of the building has not changed at all from 'tranvía' ones to high-rise buildings, but what has changed is precisely its 
154 Urban Regeneration and Sustainability

shape: a 'tranvía building' occupies more land and is shorter than a skyscraper with the same volume, which occupies less land, and as compensation, is clearly higher. The advantage of the skyscraper exempt relates to landscape, so that the owners or tourists can enjoy the wonderful views and, on the other hand, there are more free space, which favors not only the views but also the bioclimatic characteristics in the 'Ensanche'. Figure 3 depicts the evolution explained, from detached houses to 'tranvía building' and the current skyscrapers [5].

Nowadays, Benidorm is one of the scarce tourist cities that keeps the occupancy rates in hotels and other tourist amenities (apartments, camping, etc.) over the average in Spain. Thereby, at the end of 2014, the annual average occupancy in hotels was $74.9 \%$ over 37.920 rooms in 121 hotels while in Costa Blanca (Alicante Province) did not reach 65\%[1]. Anyway, there is consensus among several sociologists, researchers who had studied the city along the last decades and society as a whole about the urgent necessity of refurbishing its public space in the downtown. As an example, the average of the incomes per room is half

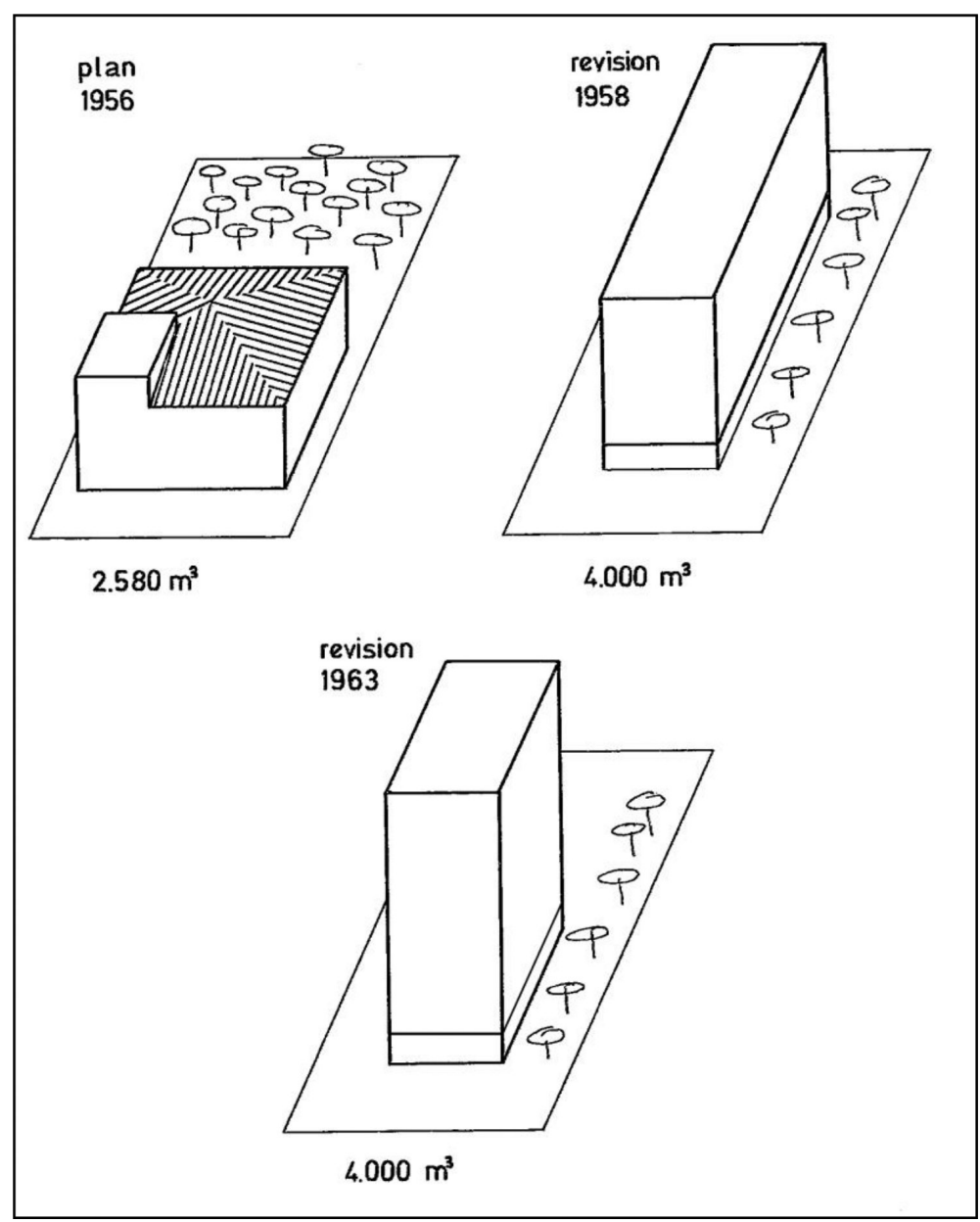

Figure 3: Building typologies evolution sketch: from detached houses to 'tranvía buildings' and, later, the current skyscrapers. 
with respect to other mass 'sun and beach' tourism cities in Spain such as San Bartolomé de Tirajana or Adeje [6].

Nevertheless, the lack of public funds not only in Valencia Community or Spain, but also in many cities and countries in the world make it almost impossible for any kind of public investment.

This setting leads to think about other forms for financing precise investment, among them, urban interventions. These formulas are known as marked-oriented instruments, and specifically in urban interventions, 'non-financial compensations'.

In this research, an urban intervention in the most emblematic area in Benidorm is proposed following these techniques.

\section{NON-FINANCIAL COMPENSATIONS: DEFINITION AND SOME EXAMPLES IN THE WORLD}

Although in most developed countries spatial planning still reflects a strong awareness of the need for a more balanced and sustainable spatial development with provisions for additional space for future development, it is increasingly assumed that it is the market, not the state, which should resolve planning problems either with or without minimal (financial) public intervention. In that way, essentially, non-financial compensations relates to the government does not financially compensate a landowner for his loss of rights, but instead gives him a right that represents a financial value [7].

Next, several noteworthy examples where this kind of market-oriented development has been applied are referred, especially, those relatively similar to the case of Benidorm.

\subsection{The washington mutual tower (Seattle)}

The (former) Washington Mutual Tower, which was finished in 1988, is situated in the downtown of Seattle, and it is a very successful example of a FAR (Floor Air Ratio)-bonus program or incentive zoning which offers bonuses to developers in return for the provision of public benefits: by providing the amenities, in particular affordable housing, but also a well-appreciated atrium that is even used for weddings, the designers were able to add 28 of its 55 stories to the skyscraper and almost double the base floor area ratio of the site (Fig. 4). The building was built on the site of the 12-storey Savoy Hotel which was imploded in 1986 [8, 9].

\subsection{Saitama city (Tokyo)}

Saitama City is part of Saitama prefecture and is located $30 \mathrm{~km}$ from Tokio. Its population is increasing due to the influx of families, the majority of whom work in Tokio but who prefer to live in Saitama. Due to that increase of population many high-rise building are being built.

Just on the west side of Yono station, the area to analyze is called Asahi Machi, which is a former low-rise high-density area of 0.6 hectares consisting of 110 different owners. To redevelop this area, two high-rise were planned and finally built. The owners, under an association which represented them, were compensated for this by receiving a certain portion of building floors in the renewed building, and, dependent on their previous tenure, shared ownership of the land. At the same time, the landowner owns, together with the leaseholders and the building owners, a certain portion of the high-rise building. Excess floor was sold to outsiders by the redevelopment association, although the major source of revenue comes from the disposal of the reserved floors (Fig. 5). The national government also provided a subsidy for dismantling of buildings and the provision of public facilities such as roads and parks [10]. 
156 Urban Regeneration and Sustainability

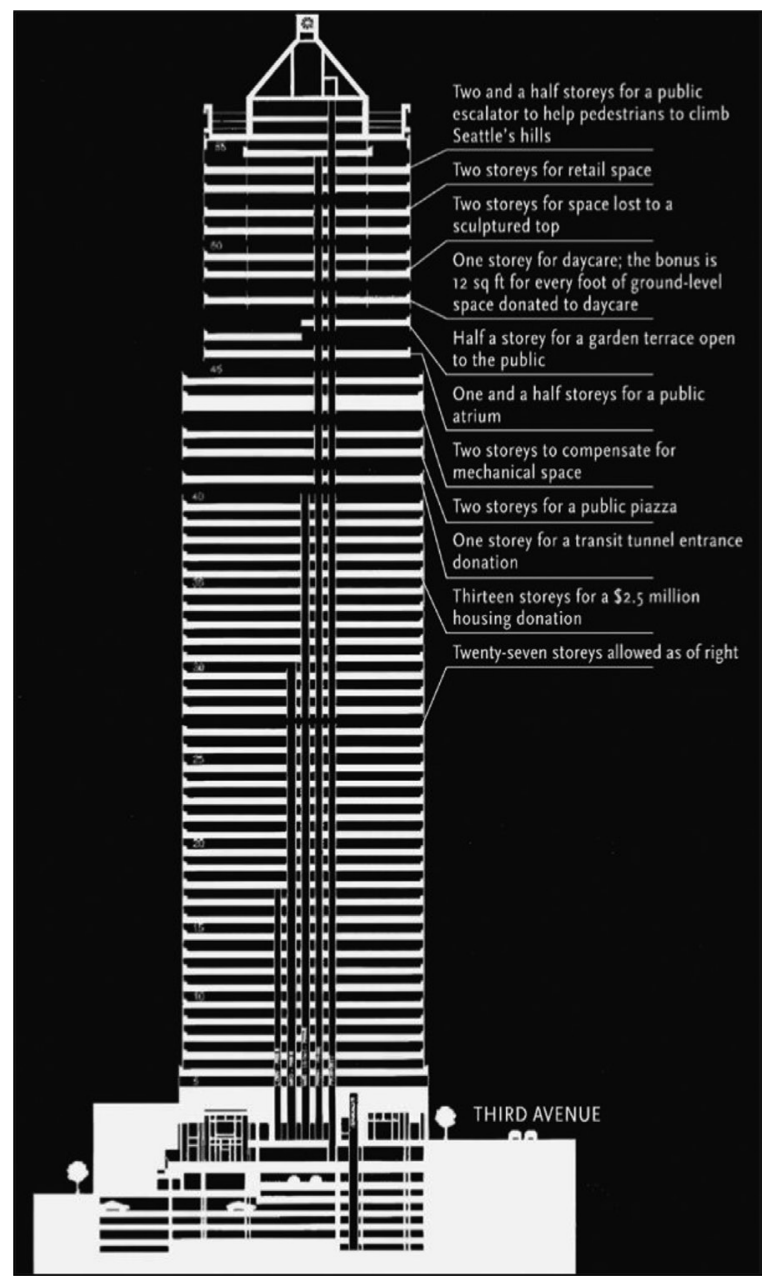

Figure 4: Incentive Zoning in Seattle, Washington Mutual tower.

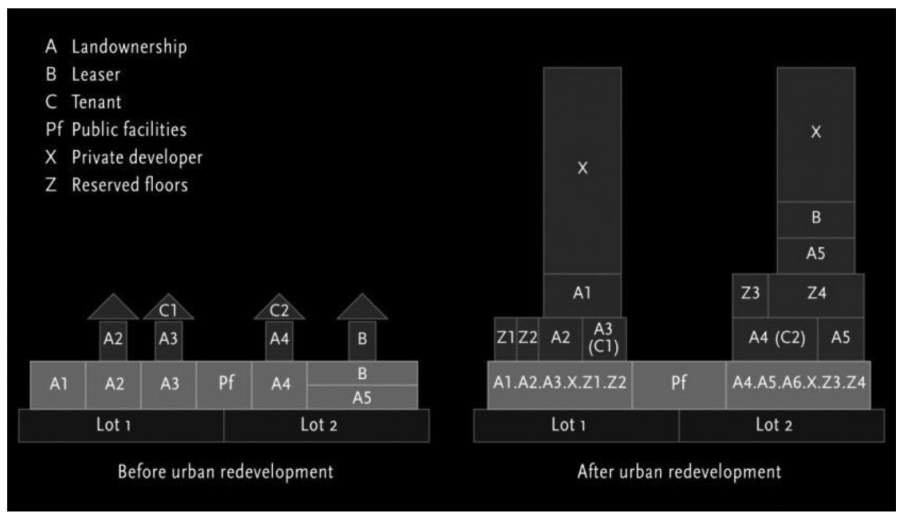

Figure 5: Saitama City, right conversion system applied in the Asahi Machi Area. 


\section{AREA SELECTED IN BENIDORM FOR URBAN MORPHOLOGY REDEVELOPMENT AND PROPOSALS FOR ACTION}

The area selected for remodeling is referred to 'tranvía buildings' located in Levante Beach, a paradigmatic space in the city.

Benidorm's residential buildings are very degraded in the core of the city due to lack of remodeling work. One of the clearest examples of this deterioration is found in Levante Beach, whose first line of buildings includes three residential buildings (Túgar, Ronda and La Gavina) and one hotel (Selomar), 'tram buildings', all of them (Fig. 6) that represent the tourist origin of the city but currently have a deplorable appearance that does not meet the requirements of a very busy tourist destination. Moreover, the surrounding public space is quite damaged. Figure 7 allows identifying this group of buildings thanks to the green net covering the Selomar Hotel.

Therefore, the proposal (currently in discussion with the Town Hall) consists of replacing these four buildings for two new skyscrapers built over two large square blocks. These new buildings would reflect an iconic character that would promote one of the busiest parts of the city and would improve the city standards of architectural quality. In addition, these buildings would fit perfectly in the skyline which is clearly dominated by skyscrapers (Fig. 8).

These buildings would have a variety of uses, such as commercial, residential, hoteliers, etc. This is one of the key aspects of the remodeling because, as mentioned, it is intended to revive the spirit of renovation in the hotel sector and to improve the urban fabric of the city while minimizing the cost of the public administrations and attracting private investment.

In addition, this transformation would also affect the public space of the surrounding streets, since the proposal would free up more public space and would improve access to the beach in the area. The proposal also includes a profound renovation of the appearance of this iconic area.

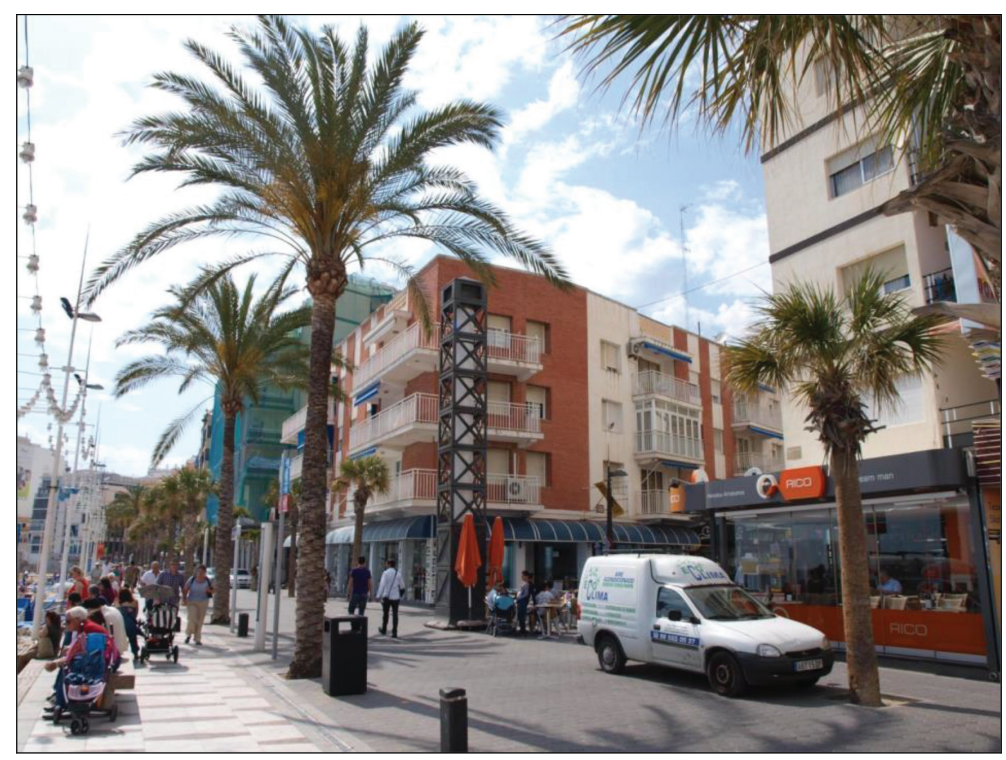

Figure 6: Old 'Tranvía Buildings' in Levante Beach, Benidorm. 
158 Urban Regeneration and Sustainability

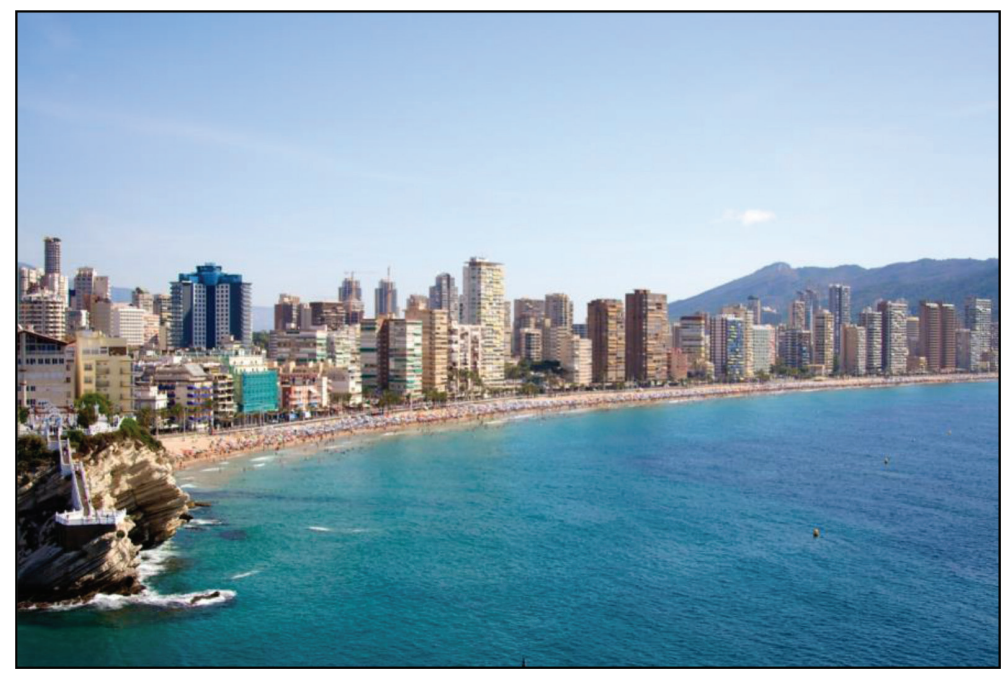

Figure 7: Current landscape of Playa de Levante with several old 'tranvía' buildings on the left.

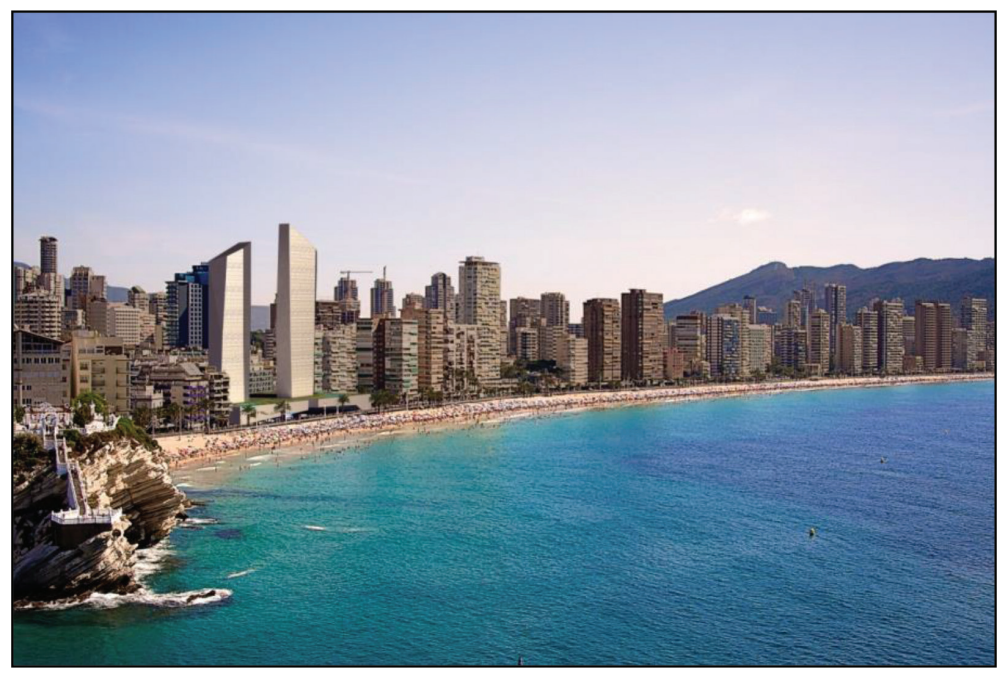

Figure 8: Current landscape of Playa de Levante including the proposed skyscrapers on the left.

Constructability has to be increased to facilitate the management of this operation, i.e. to provide incentives to both the current owners and the potential investors to convince them to accept the proposal. Increased constructability should persuade the current owners of the Ronda, Túgar and La Gavina buildings and the Selomar Hotel to join the development of the proposal.

As noted, this proposal would be carried out by using non-financial compensation instruments to avoid spending public funds. 


\section{CONCLUSIONS}

This article has tried to achieve two objectives: First, it outlined the evolution of Benidorm urban layout and morphology, from its intense transformation in the 1960s to its present tourist development marked by skyscrapers and mixed uses, highlighting the influence of the different social agents and urban development plans over its current configuration.

Second, taking into account the scarcity of public funds, this article presented several intervention formulas to adapt Benidorm urban space to the new tendencies and to maintain adequate environmental and architectural quality standards.

In particular, this article presented a proposal to redevelop the old-fashioned residential buildings of the centre of Benidorm through market-oriented compensations instruments. One of these instruments is the non-financial compensation scheme, which encompasses the Transferable Development Rights -TDR- scheme, which is commonly used in the USA, and the incentive zoning system, which is used in many other developed countries.

\section{ACKNOWLEDGEMENTS}

Antonio-Manuel PuchadesOrts, privatedeveloper in Benidorm.

Manuel Beltrá Vidal, Alejandro Espinosa Blasco and Miguel Fernández Berenguer, e2b Arquitectos.

José-Ramón Navarro Vera, Spatial Planning Professor at University of Alicante.

Manuel BeltráMartínez, Spatial Planning Lecturer at the University of Alicante.

ÁngelRosiqueVegal, photographer of Benidorm.

Patricia FernándezAracil, University Institute of the Water and the Environmental Sciences, University of Alicante.

\section{REFERENCES}

[1] Instituto Nacional de Estadística, Padrón Municipal de 2014,Encuesta de Ocupación en alojamientos turísticos: establecimientos hoteleros \& Encuesta de población activa tercer trimestre 2012, available at www.ine.es

[2] Gaviria, M., Enamorados de Benidorm 2: Macromagnitudes, Ayuntamiento de Benidorm: Benidorm, 2010.

[3] EMMA Aeropuerto de Alicante, Modos de Acceso y Lugar deprocedencia, Aeropuertos Españoles y Navegación Aérea (AENA): Madrid, 2007.

[4] Concejalía de Urbanismo del Ayuntamiento de Benidorm, Plan General de Ordenación Urbana, Ayuntamiento de Benidorm: Benidorm, 1953.

[5] Gaviria, M., Iribas, J.M., Sabbah, F. \& Sanz, J.R., Benidorm, ciudad nueva, Nacional: Madrid, 1977.

[6] Exceltur, Barómetro de la rentabilidad y el empleo de los destinos turísticos españoles, available at www.exceltur.org

[7] Janssen, L., Spaans, M. \& Van der Veen, M. (eds), New Instruments in Spatial Planning: An International Perspective on Non-Financial Compensation, IOS Press: Amsterdam, 2008.

[8] Pacione, M., Urban Geography: a Global Perspective, Routledge: London, 2001. http://dx.doi.org/10.4324/9780203454626

[9] Van der Veen, M.,Spaans, M., Putters, B. \& Janssen-Jansen, L., Comparing the cases and planning for the future of non-financial compensation (Chapter 11). New Instruments in Spatial Planning: An International Perspective on Non-financial Compensation, eds. L. Janssen, M. Spaans \& M. Van der Veen, IOS Press: Amsterdam, pp. 229$254,2008$. 
160 Urban Regeneration and Sustainability

[10] Chorus, P., Japan: using developing rights as driver for development (Chapter 3). New Instruments in Spatial Planning: An International Perspective on Non-Financial Compensation, eds. L. Janssen, M. Spaans \& M. Van der Veen, IOS Press: Amsterdam, pp. 41-72, 2008. 